\title{
Changing ecology of Lake Victoria cichlids and their environment: evidence from $\mathrm{C}^{13}$ and $\mathrm{N}^{15}$ analyses
}

\author{
Jacco C. van Rijssel • Robert E. Hecky • \\ Mary A. Kishe-Machumu • F. Witte
}

Received: 6 January 2016/Revised: 13 April 2016/Accepted: 18 April 2016/Published online: 11 May 2016

(C) The Author(s) 2016. This article is published with open access at Springerlink.com

\begin{abstract}
Eutrophication is an increasing global threat to freshwater ecosystems. East Africa's Lake Victoria has suffered from severe eutrophication in the past decades which is partly responsible for the dramatic decline in haplochromine cichlid species diversity. However, some zooplanktivorous and detritivorous haplochromine species recovered and shifted their diet towards macro invertebrates and fish. We used four formalin preserved cichlid species caught over the past 35 years to investigate whether stable isotopes of these fish are reflecting the dietary changes, habitat differences and if these isotopes can be used as
\end{abstract}

Guest editors: S. Koblmüller, R. C. Albertson, M. J. Genner, K. M. Sefc \& T. Takahashi / Advances in Cichlid Research II: Behavior, Ecology and Evolutionary Biology

Electronic supplementary material The online version of this article (doi:10.1007/s10750-016-2790-y) contains supplementary material, which is available to authorized users.

J. C. van Rijssel · F. Witte

Institute of Biology Leiden, Leiden University, Leiden,

The Netherlands

J. C. van Rijssel · F. Witte

Naturalis Biodiversity Center, Leiden, The Netherlands

Present Address:

J. C. van Rijssel ( $\square)$

Fish Ecology and Evolution, EAWAG Center of Ecology, Evolution and Biogeochemistry, Kastanienbaum, Switzerland e-mail: jacco.vanrijssel@eawag.ch indicators of eutrophication. We found that $\delta^{15} \mathrm{~N}$ signatures mainly reflected dietary shifts to larger prey in all four haplochromine species. Shifts in $\delta^{13} \mathrm{C}$ signatures likely represented habitat differences and dietary changes. In addition, a shift to remarkably heavy $\delta^{13} \mathrm{C}$ signatures in 2011 was found for all four species which might infer increased primary production and thus eutrophication although more research is needed to confirm this hypothesis. The observed temporal changes confirm previous findings that preserved specimens can be used to trace historical changes in fish ecology and the aquatic environment. This highlights the need for continued sampling as this information could be of essence for reconstructing and predicting the effects of environmental changes.

\footnotetext{
J. C. van Rijssel

Institute of Ecology and Evolution, University of Bern, Bern, Switzerland

R. E. Hecky

Large Lakes Observatory, University of Minnesota, Duluth, MN, USA

M. A. Kishe-Machumu

Tanzania Fisheries Research Institute, Dar es Salaam, Tanzania
} 
Keywords Diet shift - Eutrophication - Museum specimens $\cdot$ Primary production $\cdot$ Stable isotopes . Stenotopic

\section{Introduction}

Eutrophication of freshwater ecosystems is increasingly common and is a major threat to biodiversity and to aquatic resource use by local human populations (Smith \& Schindler, 2009). Most eutrophication assessment methods identified increased primary production as the immediate biological response to nutrient enrichment (Ferreira et al., 2011); and consequently, primary productivity has been recommended to be a sensitive and accurate indicator of eutrophication (Paerl et al., 2003; Andersen et al., 2006) with some exception Garmendia et al. (2013) and Smith (2007). Increased primary productivity and nutrient enrichment generally result in the preferential removal and depletion of lighter ${ }^{12} \mathrm{C}$ leading to heavier $\delta^{13} \mathrm{C}$ signatures in aquatic food chains (Schelske \& Hodell, 1991). Increased nitrogen pollution from runoff is reflected by heavier $\delta^{15} \mathrm{~N}$ signatures while a high $\mathrm{N}$ demand by primary producers can favour $\mathrm{N}$-fixing cyanobacteria and consequently lighter $\delta^{15} \mathrm{~N}$ signatures (Peterson \& Fry, 1987). Therefore, both carbon and nitrogen stable isotopes are sensitive to nutrient enrichment and increased primary productivity (Schelske \& Hodell, 1991; Cabana \& Rasmussen, 1996; Vander Zanden et al., 2005; Gu et al., 2006), and thus might be useful indicators of eutrophication.

Besides being used as indicators of primary productivity and of changes in basal signatures in food webs, stable isotopes are commonly used to function as estimators of trophic position and carbon flow in aquatic food webs (Peterson \& Fry, 1987; Post, 2002). The $\delta^{15} \mathrm{~N}$ signatures of consumers are typically enriched with 3-4\%o with each trophic level while the $\delta^{13} \mathrm{C}$ signatures are similar or only slightly enriched $\left(\delta^{13} \mathrm{C}<1 \%\right.$ ) (Peterson \& Fry, 1987; Vander Zanden $\&$ Rasmussen, 2001). Stable isotopes can also provide information on the habitat of aquatic species. In general, limnetic phytoplankton photosynthesis results in lighter $\delta^{13} \mathrm{C}$ signatures compared to heavier $\delta^{13} \mathrm{C}$ signatures produced by benthic algae photosynthesizing within a boundary layer (France, 1995; Hecky \& Hesslein, 1995). This phenomenon makes it possible to infer whether the prey of primary consumers has a benthic, littoral or limnetic origin (Hecky \& Hesslein, 1995; Vander Zanden \& Rasmussen, 1999). Stable isotopes of primary consumers are also related to the habitat gradient, with light $\delta^{13} \mathrm{C}$ and heavy $\delta^{15} \mathrm{~N}$ signatures in profundal habitats and vice versa in littoral habitats (Vander Zanden \& Rasmussen, 1999).

Lake Victoria has suffered from severe eutrophication in the past decades, and the shallow, inshore habitats especially have high algal biomasses and a high carbon demand by photosynthesis (Ramlal et al., 2001; Hecky et al., 2010). Based on paleolimnological analyses, changes in lower food web organisms began as early as the 1940s but accelerated dramatically through the 1960s and 1970s (Verschuren et al., 2002; Hecky et al., 2010). From the 1980s onwards, several studies have shown increased nitrogen and phosphorus loadings in the lake coinciding with decreased water transparency and oxygen levels (Mugidde, 1993; Hecky et al., 1994, 2010; Seehausen et al., 1997a; Verschuren et al., 2002). The eutrophication is thought to be caused by agricultural malpractices, urbanization and deforestation, although recent studies have suggested that climatic variability and wind stress played a crucial role as well (Kolding et al., 2008; Hecky et al., 2010; van Rijssel, 2014). Most of the studies reporting eutrophication focussed on the northern part of the lake (Hecky, 1993; Mugidde, 1993; Mugidde et al., 2003) and because of the lack of regular and consistent measurements of biological productivity, paleolimnological analysis was used to provide more continuous analysis of historical changes in the ecosystem.

For the Mwanza Gulf, located in the southern part of the lake, even less data on productivity are available (Akiyama et al., 1977; Shayo et al., 2011; Cornelissen et al., 2014), although other environmental variables such as dissolved oxygen levels and Secchi depth data have been measured on a fairly regular basis in the last four decades (van Rijssel, 2014). In addition, the Lake Victoria biodiversity crisis has been well documented for the Mwanza Gulf from the 1970s onwards (Witte et al., 2007). In the 1980s, the introduced Nile perch, Lates niloticus, population boomed. The Nile perch is thought to have contributed to the eutrophication of Lake Victoria as well by accelerating and subsidizing productivity of the ecosystem through high turnover of fish biomass and consequently more rapid recycling of 
nutrients (Kolding et al., 2008). Together with the eutrophication, the Nile perch boom caused a major decline of cichlid species (Witte et al., 1992; Seehausen et al., 1997a; Goudswaard et al., 2008). However, during the 1990s, some cichlid species, especially zooplanktivores and detritivores, recovered (Seehausen et al., 1997b; Witte et al., 2007; KisheMachumu et al., 2015) and shifted their diet towards macroinvertebrates and fish (Van Oijen \& Witte, 1996 Katunzi et al., 2003; Kishe-Machumu et al., 2008; van Rijssel et al., 2015). With the use of formalinpreserved cichlid specimens collected over the past 35 years, we demonstrated that the recovered species showed morphological adaptive responses to the environmental changes (Witte et al., 2008; Van der Meer et al., 2012; Van Rijssel \& Witte, 2013; van Rijssel et al., 2015).

Here, we use these unique cichlid museum specimens selected at triennial time intervals from 1978 onwards, to test how the environmental and ecological changes might be reflected in the $\mathrm{C}$ and $\mathrm{N}$ stable isotopes of these fish and if they can be used as indicators of eutrophication. In addition, we investigated whether habitat and seasonal changes were reflected in these isotopes as not all fish were caught at the exact same location and period on the research transect.

For this study, we used two closely related zooplanktivorous species (abbreviations of species in parentheses) Haplochromis (Yssichromis) pyrrhocephalusWitte \& Witte-Maas 1987(pyr), H.(Y.) laparogramma Greenwood \& Gee 1969 (lap), the zooplankti/insectivorous species $H$. tanaos van Oijen 1996 (tan) and the mollusci/detritivorous species Platytaeniodus degeniBoulenger 1906(deg). Dietary gut content analyses revealed that the species pyr and lap shifted their diet towards large macroinvertebrates such as aquatic insects, shrimps and molluscs as well as to fish during the 1990s, but reverted their diet (partly) back to zooplankton in the 2000s which is their original diet (Katunzi et al., 2003; KisheMachumu, 2012; van Rijssel et al., 2015). These two species also extended their habitat to shallower waters (Seehausen et al., 1997b; Kishe-Machumu et al., 2015). The species tan and deg both showed the most pronounced diet changes towards macroinvertebrates and fish during the 2000s and have extended their habitat to deeper waters (Van Oijen \& Witte, 1996; Seehausen et al., 1997b; Kishe-Machumu et al., 2015; van Rijssel et al., 2015).
There are no substantial changes over time in the sedimentary $\delta^{15} \mathrm{~N}$ of the lake based on results from three sediment cores from various locations in northern Lake Victoria (R. E. Hecky, unpubl. data). Therefore, we expect the dietary changes to be reflected in the $\delta^{15} \mathrm{~N}$ signatures of the cichlids as was found by Kishe-Machumu et al. (this issue). However, the response of $\delta^{15} \mathrm{~N}$ in fish muscle could be more complex as shifts in basal signature in phytoplankton will be additive to possible shifts in diet to prey which might be lighter or heavier in $\delta^{15} \mathrm{~N}$.

The eutrophication of the lake coincided with increased primary productivity, altered species composition and higher abundance of phytoplankton in the northern part (Hecky, 1993; Verschuren et al., 2002) as well as in the southern part of the lake (Cornelissen et al., 2014). The shift from diatoms to cyanobacterial phytoplankton dominance was accompanied with an increase of $2 \%$ in the (Suess corrected) $\delta^{13} \mathrm{C}$ of organic matter in sediment cores (Hecky et al., 2010). This probably occurred as the higher biomass of filamentous and colonial cyanobacteria raised the demand for $\mathrm{CO}_{2}$ relative to availability in this soft water lake (Ramlal et al., 2001) and also may have decreased isotopic fractionation by boundary layer effects in the larger filamentous and colonial cyanobacteria (Hecky \& Hesslein, 1995). Therefore, we expect $\delta^{13} \mathrm{C}$ signatures may have shifted towards heavier values in these cichlids even without shifts in their diets, especially in inshore habitats. In any case, we hypothesized that changes in the environment and in the fish's trophic level may be evident in the isotopic composition of the historical collection of haplochromine fishes from the Mwanza Gulf.

\section{Methods}

Fish collection

Most fish were collected from a research transect in the northern part of the Mwanza Gulf (6-14 m) on the southern coast of Lake Victoria. Fish were caught with a bottom trawler during the period 1978-2011. The species pyr and lap and were mainly caught above mud at station G (12-14 m) of the transect. Selected pyr specimens from 1987 were from Luanso Bay (Goldschmidt et al., 1993), a shallow bay (3-4 m) 10 kilometres south of the transect, as no pyr specimens 
caught on the transect in 1987 were preserved. The species tan and deg were mainly caught at sand/mud bottoms (Butimba and Kissenda Bay) at the opposite ends of the transect (Fig. 1). Fish were preserved in $4 \%$ formaldehyde (buffered with borax) and after shipment to Leiden, The Netherlands transferred to $70 \%$ ethanol and stored at theNaturalis Biodiversity Center. Species determination and distinction occurred for each individual in the field. F. Witte was responsible for the species re-determination for

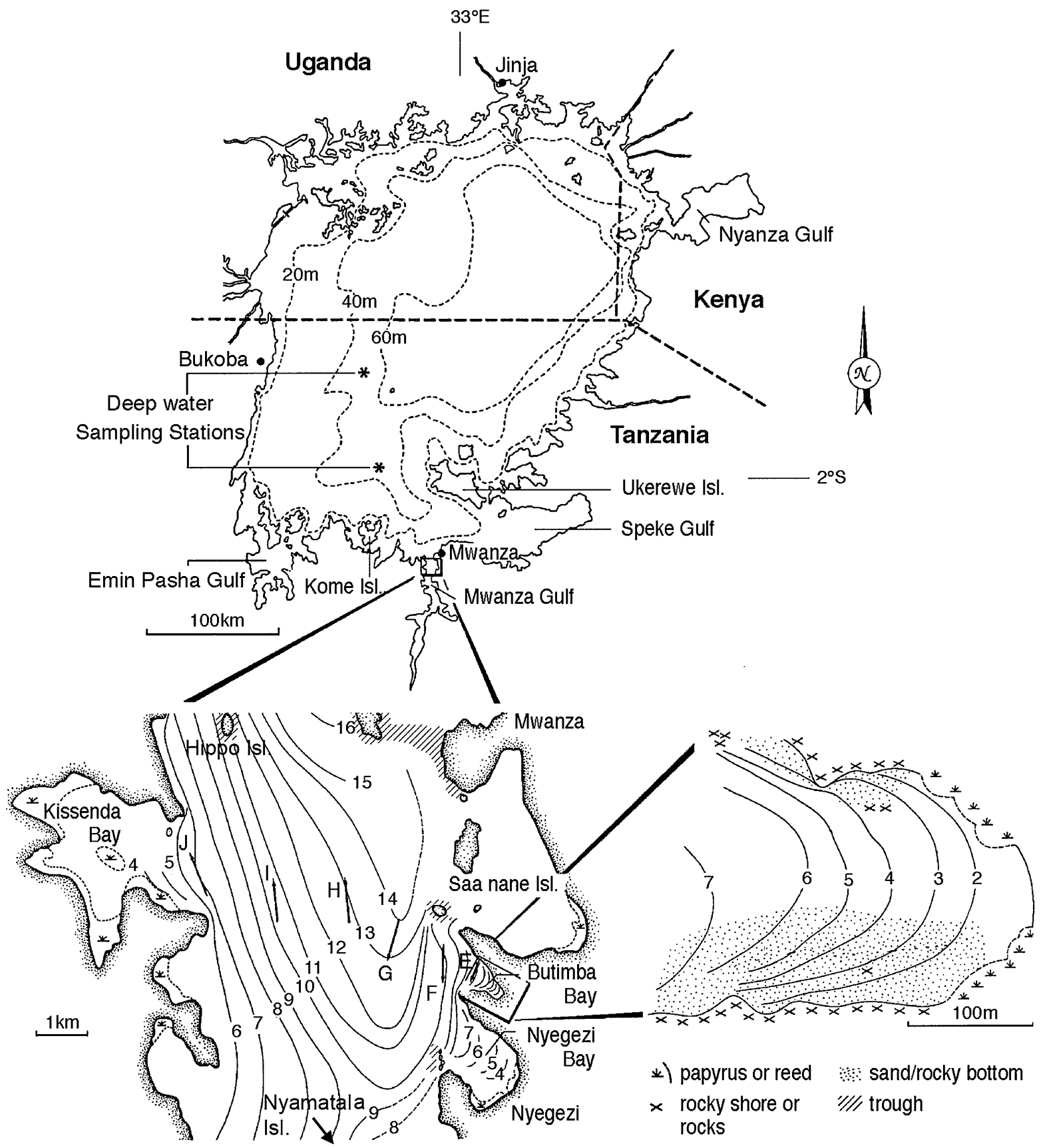

Fig. 1 Map of Lake Victoria with the sampled research transect in the Mwanza Gulf. Sampling stations are indicated with diagonal lines, contour lines are isobaths indicating depth in metres 
every preserved individual. A total of 273 male specimens (eight fish per year per species on average) was selected from the years 1978, 1981, 1984, 1987, 1991, 1993, 1999, 2001/02, 2006 and 2011 which is a selection from the same specimens used by van Rijssel $\&$ Witte (2013) and van Rijssel et al. (2015) (Table S1 in Electronic Supplementary Material).

Stable isotope analysis

From each fish, the right side of the epaxial muscle located dorsal of the lateral line was dissected after removal of the skin. These muscle tissue samples were freeze dried for $72 \mathrm{~h}$ and ground into fine powder. A subsample of $1.25 \mathrm{mg}$ was placed into tin cups and shipped to the UC Davis Stable Isotope Facility for analysis. Stable isotope analysis of ${ }^{13} \mathrm{C}$ and ${ }^{15} \mathrm{~N}$ was carried out with a PDZ Europa ANCA-GSL elemental analyzer interfaced to a PDZ Europa 20-20 continuous flow isotope ratio mass spectrometer (IRMS). The $\delta^{13} \mathrm{C}$ and $\delta^{15} \mathrm{~N}$ values were expressed relative to international reference standards V-PDB (Vienna Pee Dee Belemnite) and air, respectively. The difference $(\delta)$ in isotopic ratio between the sample and standards was calculated as follows:

$\begin{aligned} & \delta^{13} C \text { or } \delta^{15} N=\left(R_{\text {sample }}-R_{\text {standard }}\right) /\left(R_{\text {standard }}\right) \\ & \times 1000\end{aligned}$

where $R={ }^{13} \mathrm{CO}_{2} /{ }^{12} \mathrm{CO}_{2}$ for $\delta^{13} \mathrm{C}$ or $R={ }^{15} \mathrm{~N}_{2} /{ }^{14} \mathrm{~N}_{2}$ for $\delta^{15} \mathrm{~N}$ and values are expressed as \%o.

Glutamic acid, nylon and bovine liver which were similar in composition as the samples being used were used as standards. These standards were previously calibrated against NIST Standard Reference Materials such as IAEA-N1, IAEA-N2, IAEA-N3, USGS-40 and USGS-41.

Due to deforestation and fossil fuel burning which is naturally depleted in $\delta^{13} \mathrm{C}$, atmospheric $\mathrm{CO}_{2}$ levels have been increasing while $\delta^{13} \mathrm{C}$ of $\mathrm{CO}_{2}$ has declined, especially over the past 35 years (Francey et al., 1999). This decrease in $\delta^{13} \mathrm{C}$ of atmospheric $\mathrm{CO}_{2}$ due to anthropogenic perturbations is known as the Suess effect (Keeling, 1979) and is most severe as the present day is approached (Verburg, 2007). As atmospheric and aquatic $\mathrm{CO}_{2}$ equilibrate rapidly in the upper mixed layer of lakes and oceans, it was necessary to apply a Suess correction in order to compare $\delta^{13} \mathrm{C}$ signatures of fish collected over the last 35 years according to the following formula:

$$
\begin{aligned}
& 7.7738118 \times 10^{-16} \times Y^{6}-1.2222044 \times 10^{-11} \\
& \times Y^{5}+7.1612441 \times 10^{-8} \times Y^{4} \\
& -2.1017147 \times 10^{-4} \times Y^{3}+3.3316112 \times 10^{-1} \\
& \times Y^{2}-273.715025 \times Y+91703.261,
\end{aligned}
$$

with $Y$ as year since 1700 , as recommended by Verburg (2007). The Suess correction was subtracted from $\delta^{13} \mathrm{C}$ values of the years 1981-2011 with the smallest correction for $1981(-0.07 \%)$ and the largest correction for $2011(-1.09 \%$ )

Kishe-Machumu et al. (this issue) showed that formalin/ethanol preservation had a small but consistent effect on the stable isotopes of Lake Victoria cichlids. The preservation depleted $\delta^{13} \mathrm{C}$ with $0.66 \%$ and $\delta^{15} \mathrm{~N}$ values increased on average with $0.34 \%$, which is consistent with directional shifts induced by formalin and ethanol preservation of fish reported in previous studies (Arrington \& Winemiller, 2002; Sarakinos et al., 2002; Kelly et al., 2006; GonzalezBergonzoni et al., 2015). So far, studies on long-term preservation effects of fish stable isotopes showed that these are independent of time (Kaehler \& Pakhomov, 2001; Ogawa et al., 2001; Ponsard \& Amlou, 1999; Sarakinos et al., 2002; Sweeting et al., 2004) which we assume is also the case for the cichlids used in this study. Although all fish of our study have been preserved, the same way over time and preservation effects are expected not to influence our results, we corrected the $\delta^{13} \mathrm{C}$ and $\delta^{15} \mathrm{~N}$ values for preservation effects with $+0.66 \%$ and $-0.34 \%$, respectively (as reported by Kishe-Machumu et al., this issue) to approach more accurate stable isotope signatures.

Lipids are also known to influence $\delta^{13} \mathrm{C}$ analyses by fractionation which results in differences between $\delta^{13} \mathrm{C}$ values of lipids and other tissue like protein in a single organism (Deniro \& Epstein, 1977; Mcconnaughey \& Mcroy, 1979; Sweeting et al., 2006). Lipid content of tissue can be estimated by its $\mathrm{C}: \mathrm{N}$ ratio (Mcconnaughey \& Mcroy, 1979) after which a mathematical normalization technique can be applied to correct $\delta^{13} \mathrm{C}$ values for lipid content. By plotting $\delta^{13} \mathrm{C}$ values of each sample against its $\mathrm{C}: \mathrm{N}$ ratio, we found a minor (slope $=-0.02$ ), but significant $(P<0.001)$ effect of lipids in our dataset with lower lipid contents in more recent years (Fig. S1). We 
corrected the dataset for lipid content using the formula:

$\delta^{13} \mathrm{C}_{\text {normalized }}=\delta^{13} \mathrm{C}_{\text {untreated }}-3.32+0.99 \times \mathrm{C}: \mathrm{N}$

which is proposed by Post et al. (2007) to use for aquatic organisms where $\delta^{13} \mathrm{C}_{\text {normalized }}$ is the $\delta^{13} \mathrm{C}$ value normalized for lipid content and is comparable with $\delta^{13} \mathrm{C}$ after chemical lipid extraction. Fish samples without any lipids have a $\mathrm{C}: \mathrm{N}$ ratio close to 3.0 (Kiljunen et al., 2006; Post et al., 2007). The average lipid content ( $\mathrm{C}: \mathrm{N}$ ratio) per sample in our study was fairly low (3.4, which is equal to $4.3 \%$ lipid), and it would therefore not be necessary to account for lipids (Post et al., 2007). Nonetheless, we corrected the samples for lipid content in order to adjust for the minor but significant trend found between $\delta^{13} \mathrm{C}$ and the lipid content.

In addition to generating stable isotope values from preserved cichlid specimens, we used stable isotope values of particulate organic matter (POM) to test how intra-lake variation in POM would influence our results. These POM stable isotope data were collected on a transect from Mwanza to Port Bell, Lake Victoria (see Fig. 2 in Hecky et al., 2010 for sampling transect). Every $20 \mathrm{~km}$, surface water samples were taken from the trans-lake ferry MV Bukoba in October 1995. Additionally, water samples were taken from location V96-5MC in the middle of the lake, from Bugaia Island in the northern part of the lake in July 1995 and April 1996 (Campbell et al., 2003a; Hecky et al., 2010) and from offshore sites XL1, XL4, XL6-9 in May 1995 (Mugidde et al., 2003). Stable isotope signatures were derived from these samples using the methods of Hecky \& Hesslein (1995) at the Freshwater Institute Laboratory (Winnipeg, Canada) and were also Suess corrected (Verburg, 2007).

\section{Statistical analysis}

We divided stable isotopes signatures into three different time periods according to van Rijssel et al. (2015). The pristine period (1978-1984), which is considered as the period before severe environmental changes; the perturbed period (1987-2002), which is considered as the period of severe environmental changes and changes in diet of the haplochromine cichlids; the recovery period (2006-2011), in which environmental changes seem less severe and some haplochromine species (partially) returned to their original diet.

To test our hypotheses on heavier $\delta^{13} \mathrm{C}$ and $\delta^{15} \mathrm{~N}$ signatures over time, we applied circular statistics using Oriana 4.0 to quantify directional food web changes following Schmidt et al. (2007). We calculated the direction (angle of change) and length (magnitude of change) of both $\delta^{13} \mathrm{C}$ and $\delta^{15} \mathrm{~N}$ combined per species over time (both for the three periods as for individual years). The directional change was calculated by considering the $\delta^{13} \mathrm{C}$ and $\delta^{15} \mathrm{~N}$ values as $x, y$ coordinates where delta $\mathrm{y}\left({ }^{15} \mathrm{~N}\right)$ was divided by delta $\mathrm{x}\left({ }^{13} \mathrm{C}\right)$. These values were then converted into
Fig. 2 Arrow histograms of the angle of isotopic change between a the pristine and perturbed period, $\mathbf{b}$ the perturbed and recovery period for all four cichlid species. Arrows represent the direction and magnitude of isotopic change. The straight dashed line represents the mean vector of change; the curved dashed line on the rim represents the $95 \%$ confidence interval around the mean vector of change
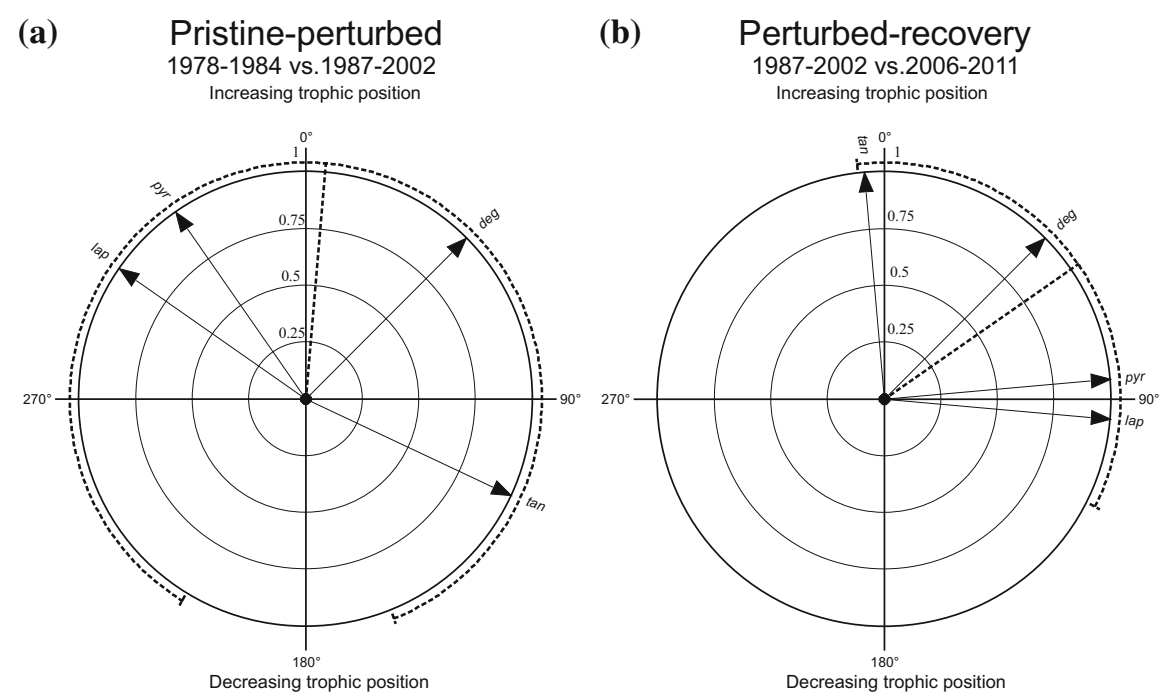
angles using the ATAN function in Excel. The direction (mean angle, $\mu$ ) and the length $(r)$ of the mean vector of all the species of the same period were calculated where $(r)$ provides a unit of concentration of turning angles, $r$ values close to 0 indicate that the directions are uniformly distributed, $r$ values close to 1 indicate all angles are concentrated in the same direction. Angular standard deviation is given as measure of angular variance. We constructed arrow diagrams to visualize the direction and magnitude of each food web component. We used both Rayleigh's test as Rao's spacing test to assess whether the direction of the angles was uniformly distributed (null hypothesis).

Differences in stable isotopes per year were also tested with a One-way ANOVA. To test if standard length (SL) influences the stable isotopes of the fish, a Pearson correlation test was used after testing for normality with a Shapiro-Wilks test. In three out of four species (lap, pyr \& tan), only five significant correlations between $\delta^{13} \mathrm{C}$ and SL were found within years. There were no significant correlations between $\delta^{15} \mathrm{~N}$ and SL within years. Because there was no consistent trend and the correlations occurred in both positive and negative direction within a species, we decided not to correct for SL (Table S2).

To test if the number of different catch locations per year influenced the variation in stable isotopes, we correlated this number with the standard deviation (SD) of the stable isotopes per year (Table S3). We applied the same method to test for seasonal effects by correlating the number of catch dates with the SD of the stable isotopes.

Slope differences between stable isotope data of POM and preserved cichlid species were tested with an ANCOVA. All these statistical tests were performed with SPSS 20.

\section{Results}

\section{Common isotopic responses per period}

The direction of change in stable isotope signatures between the pristine and perturbed period differed between the four species (Fig. 2a; Table 1). The $\delta^{13} \mathrm{C}$ signatures of the two zooplanktivores pyr and lap changed unexpectedly towards lighter values while $\delta^{15} \mathrm{~N}$ signatures increased as expected. The $\delta^{13} \mathrm{C}$ signatures of species tan and deg increased to heavier values and where $\delta^{15} \mathrm{~N}$ signatures increased for $\mathrm{deg}$, they unexpectedly decreased for tan (Fig. 2a). Arrow diagrams show that in the recovery period, stable isotope signatures of 3 out of 4 species ( $p y r$, lap and deg) changed into the expected similar direction (Fig. 2b). This is supported by Raleigh's and Rao's spacing test which both indicate almost significant patterns of consistent change $(0.10>P>0.05$; Table 1$)$ and a relatively high $r(0.78)$. The $\delta^{13} \mathrm{C}$ signatures of $p y r$, lap and $d e g$ increased while those of tan remained similar. The $\delta^{15} \mathrm{~N}$ signatures remained similar for pyr and lap while they increased for tan and deg (Fig. 2b).

Common isotopic responses per sampling year

All four species showed significant changes through time in $\delta^{13} \mathrm{C}$ (ANOVA, $P<0.001$ ) and $\delta^{15} \mathrm{~N}$ (ANOVA, $P<0.01$; Figs. 3, 4; see Table S4 for F-statistics, degrees of freedom and $P$ values). From 1978-1981, the three zooplanktivorous species shifted towards lighter $\delta^{13} \mathrm{C}$ values and heavier $\delta^{15} \mathrm{~N}$ values while the species deg shifted in the opposite direction (Figs. 3a, 4a, b, c). From 1981 to 1984, pyr, lap and deg all shifted back towards heavier isotopic $\delta^{13} \mathrm{C}$ signatures, while $\delta^{15} \mathrm{~N}$ values remained similar ( $\mu=0.86$; Rayleigh's test $P=0.10$; Table 2, Figs. 3b,4a, b, d). From 1984 to 1987, these three species all showed a striking drop in $\delta^{15} \mathrm{~N}$ signatures while $\delta^{13} \mathrm{C}$ values of lap and $\mathrm{deg}$ remained similar and those of pyr shifted towards heavier values $(\mu=0.82$; Rayleigh's test $P=0.13$; Table 2; Figs. 3c, 4a, b, d). It must be noted that specimens of pyr caught in 1987 came from the Luanso Bay, a shallow bay (3-4 m) 10 kilometres south of the transect which might be the cause of the relatively heavy $\delta^{13} \mathrm{C}$ values. In the periods 1987-1991, 1991-1993, 1993-1999 stable isotope signature of the two zooplanktivores pyr and lap both shifted towards lighter $\delta^{13} \mathrm{C}$ values and heavier $\delta^{15} \mathrm{~N}$ values (Table 2; Figs. 3d, e, f, 4a, b) while from 1999 to 2002 a major shift towards heavier $\delta^{13} \mathrm{C}$ and lighter $\delta^{15} \mathrm{~N}$ values occurred $(\mu=1.0$; Rayleigh's test $P=0.14$; Table 2; Figs. 3g, 4a, b). While the isotopic signatures of these two zooplanktivores continued to shift towards heavier $\delta^{13} \mathrm{C}$ values from 2002 to 2006, $\delta^{15} \mathrm{~N}$ values of tan increased and $\delta^{13} \mathrm{C}$ values of $\mathrm{deg}$ shifted towards lighter values (Figs. 3h, 4). From 2006 to 2011, the isotopic signatures of all four species made a major shift towards remarkably heavy $\delta^{13} \mathrm{C}$ 
Table 1 Circular statistics on changes in stable isotopes between the pristine (1978-1984), perturbed (1987-2002) and recovery period (2006-2011)

\begin{tabular}{|c|c|c|c|c|c|c|c|c|}
\hline \multirow[t]{2}{*}{ Period } & \multirow[t]{2}{*}{$\mathrm{N}$} & \multicolumn{2}{|l|}{ Mean vector } & \multirow[t]{2}{*}{ Circular SD } & \multicolumn{2}{|c|}{ Raleigh's test } & \multicolumn{2}{|c|}{ Rao's spacing test } \\
\hline & & Direction $(\mu)$ & Length $(r)$ & & $\mathrm{Z}$ & $P$ & $U$ & $P$ \\
\hline $1978-1984$ to $1987-2002$ & 4 & 4.9 & 0.41 & 76.8 & 0.66 & 0.55 & 98.3 & $0.50-0.90$ \\
\hline $1987-2002$ to $2006-2011$ & 4 & 55.2 & 0.78 & 40.2 & 2.4 & 0.08 & 170.7 & $0.05-0.10$ \\
\hline
\end{tabular}

Direction length values $(r)$ close to 1 indicate a common isotopic change in direction

values, while $\delta^{15} \mathrm{~N}$ values decreased for pyr, lap and tan during this period $(\mu=0.95$; Rayleigh's test $P=0.02$; Table 2, Figs. 3h, 4).

\section{Effect of catch location}

Fish from multiple catch locations showed a higher catch within year variation in $\delta^{13} \mathrm{C}$ compared to fish caught in years with fewer catch locations (four different species combined, Spearman correlation, $r=0.422, P=0.014)$. Since each catch location had a different depth, this means that fish caught in years with multiple catch locations were also caught from different depths. All four species showed positive (mostly non-significant) correlations between the number of catch locations per year and the SD of $\delta^{13} \mathrm{C}$. There was one significant correlation for lap ( $r=0.851, P=0.002)$ and an almost significant correlation for $\operatorname{deg}(r=0.732, P=0.061)$ between the number of catch locations per year and the SD of $\delta^{13} \mathrm{C}$ (Table 3).

The relation between the number of catch locations and the amount of within year variation in $\delta^{15} \mathrm{~N}$ was less clear and showed no significant correlations (Table 3).

The $\delta^{13} \mathrm{C}$ and $\delta^{15} \mathrm{~N}$ values of POM exhibit an inverse relationship (Fig. 5, Pearson correlation, $r=-0.50, P=0.002$ ) indicating intra-lake variation. This relationship shows that for every $1 \%$ o increase in $\delta^{13} \mathrm{C}$ (from offshore to inshore), the $\delta^{15} \mathrm{~N}$ decreases by $0.71 \%$ in POM. The species pyr, lap and tan seem to exhibit a similar trend with negative slopes of $-0.40,-0.21$ and -0.30 , respectively (Figs. $4 a-c$ ). An ANCOVA on the slopes of these species and that of POM showed that the slope of lap differed significantly $(P=0.004)$ from POM but both slopes of pyr and tan did not (Table S5). The species deg showed a positive slope $(0.41$, Fig. 4 d) which differed significantly from the slope of POM $(P<0.001$; Table S5).

Effect of catch date

There was a significant positive correlation between the number of catch dates and the SD of $\delta^{13} \mathrm{C}$ per year for $\operatorname{deg}(r=0.77, P=0.043)$ and an almost significant positive correlation for lap $(r=0.574$, $P=0.083)$. There were no significant correlations between the SD of $\delta^{15} \mathrm{~N}$ and the number of catch dates per year (Table 3).

\section{Discussion}

Stable isotope changes through time

This study shows how dietary shifts are reflected in the stable isotopes of formalin-preserved Lake Victoria cichlids. The increase of $\delta^{15} \mathrm{~N}$ values through time of all four species concurs with the reported shift in diet to larger prey for all four species. However, the hypothesized increase of $\delta^{13} \mathrm{C}$ did not occur until the 2000s, while we expected it to increase at the onset of eutrophication in 1987, the start of the perturbed period.

Diet-related stable isotope changes

Although the species shifted their diet already in 1987 (van Rijssel et al., 2015), there was no increase but a decrease in $\delta^{15} \mathrm{~N}$ values in that year. Stomach and gut content analysis revealed that the diet of the zooplanktivores consisted for a large part of detritivorous shrimps and detritus (van Rijssel et al., 2015), which explains the low $\delta^{15} \mathrm{~N}$ values. Campbell et al. (2003b) reported that Caridina (shrimps) had substantially 
(a) 1978-1981

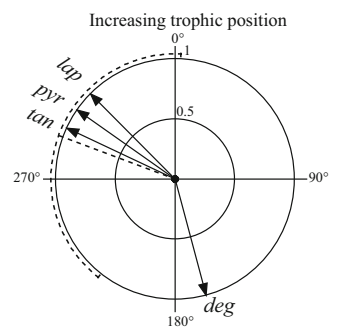

(d) 1987-1991

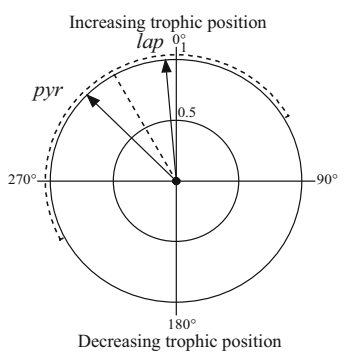

(g) 1999-2002

Increasing trophic position

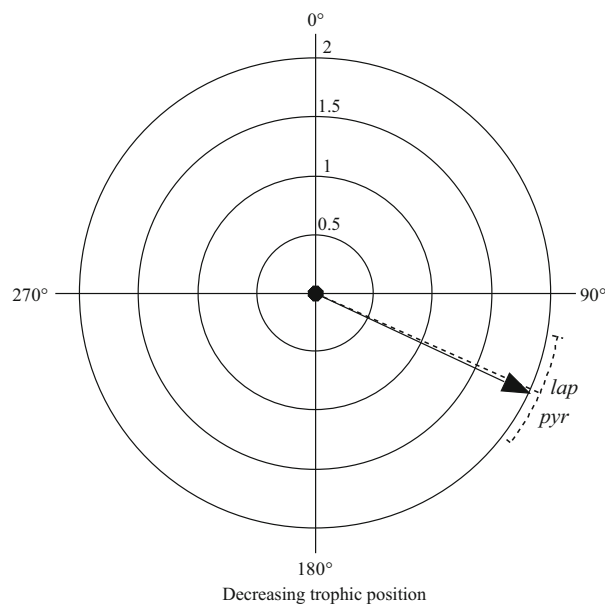

Fig. 3 Arrow histograms of the angle of isotopic change between individual years for all four cichlid fish species. Arrows represent the direction and magnitude of isotopic change. The straight dashed line represents the mean vector of change, the

lower $\delta^{15} \mathrm{~N}$ and $\delta^{13} \mathrm{C}$ than zooplankton in Napoleon Gulf in northern Lake Victoria which is in agreement with our results. Though stomach and gut contents were not analysed for $\mathrm{deg}$ in that year, based on their low $\delta^{15} \mathrm{~N}$ values and the dramatic increase of shrimps in the Mwanza Gulf during that time (Goudswaard et al., 2006; van Rijssel et al., 2015), it is likely that (c) 1984-1987

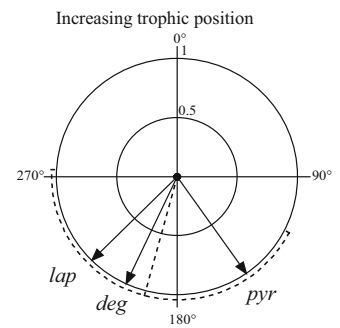

Decreasing trophic position

(f) 1993-1999

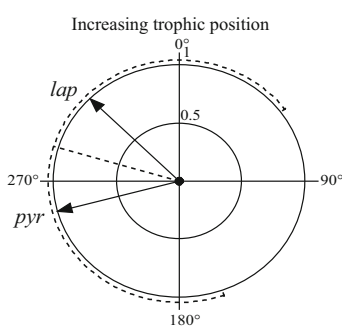

Decreasing trophic position

(i) 2006-2011

(h) 2002-2006

Increasing trophic position

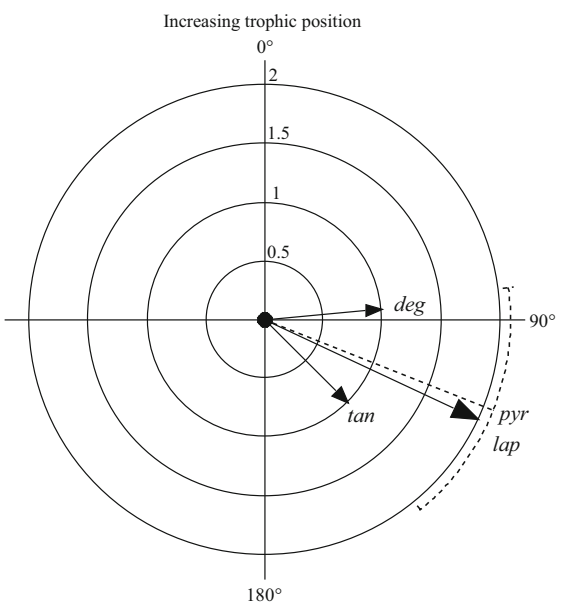

Decreasing trophic position

curved dashed line on the rim represents the $95 \%$ confidence interval around the mean vector of change. Note that only in $\mathbf{a}, \mathbf{h}$, i all four species could be included in the histogram and that axes for magnitude differ for $\mathbf{g}$ and $\mathbf{i}$

this species had shifted to a similar diet to that of the zooplanktivores.

Based on stomach and gut content analysis, the species tan shifted its diet in 1993 from zooplankton and insects to mainly insects and fish (Van Oijen \& Witte, 1996). Although higher $\delta^{15} \mathrm{~N}$ values might be expected with a shift to larger prey, tan already 
Fig. 4 The Suess corrected $\delta^{13} \mathrm{C}$ and $\delta^{15} \mathrm{~N}$

stable isotopes of the four cichlid species a $H$.

laparogramma, b $H$. pyrrhocephalus, c $H$. tanaos and $\mathbf{d} P$. degeni per year.

Linear regression lines, their slopes, $R$-squared and $P$ values are depicted for each species as a whole for comparison with particulate organic matter (POM) data, see discussion
Table 2 Circular statistics on changes in stable isotopes between the individual years

Direction length values (r) close to 1 indicate a common isotopic change in direction

Significant values are depicted in bold

n.a. Indicates that a result could not be calculated due to low sample size

Table 3 Pearson correlations per species between the number of catch locations, catch dates per year and the SD of $\delta^{13} \mathrm{C}$, $\delta^{15} \mathrm{~N}$

* Indicates Spearman correlation

Significant values are depicted in bold
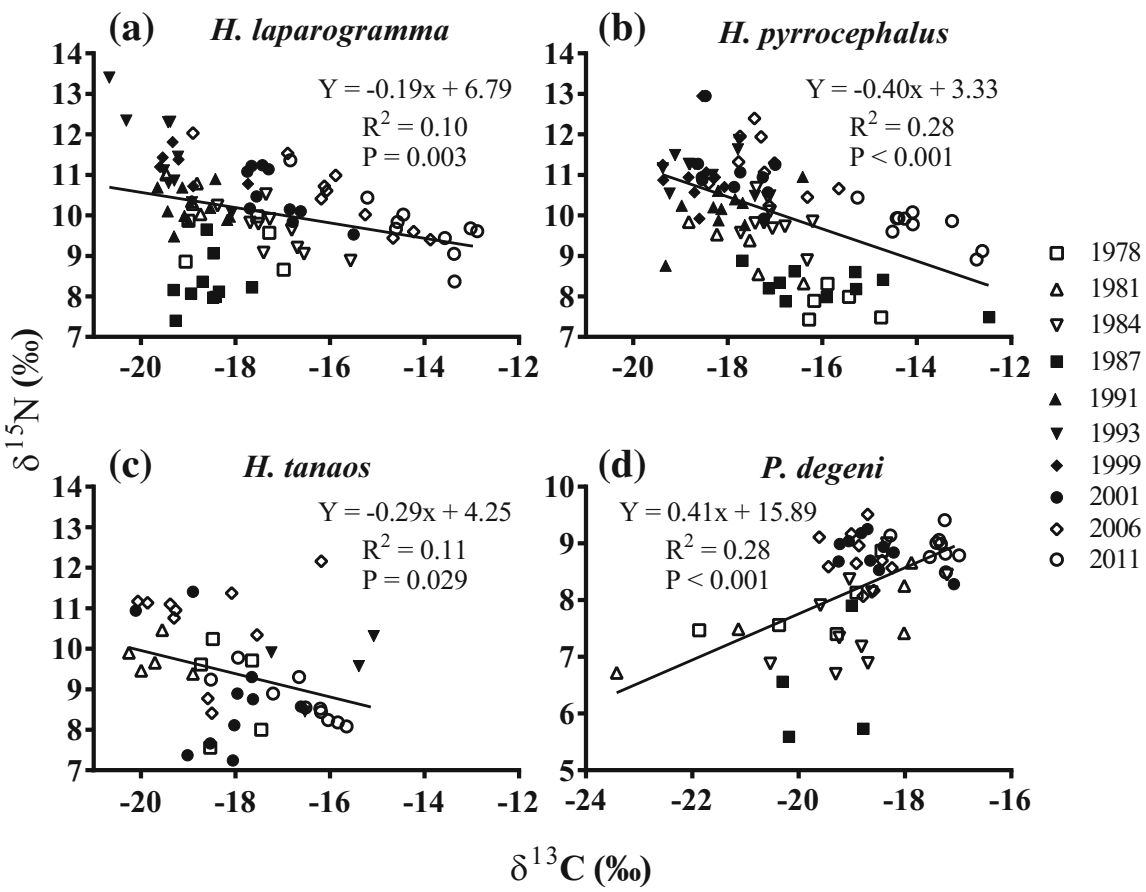

\begin{tabular}{|c|c|c|c|c|c|c|c|c|}
\hline \multirow[t]{2}{*}{ Period } & \multirow[t]{2}{*}{$N$} & \multicolumn{2}{|l|}{ Mean vector } & \multirow[t]{2}{*}{ Circular SD } & \multicolumn{2}{|c|}{ Raleigh's test } & \multicolumn{2}{|c|}{ Rao's spacing test } \\
\hline & & Direction $(\mu)$ & Length $(r)$ & & $\mathrm{Z}$ & $P$ & $U$ & $P$ \\
\hline 1978-1981 & 4 & 290.5 & 0.58 & 60.3 & 1.32 & 0.29 & 158.1 & $0.10-0.50$ \\
\hline 1981-1984 & 3 & 83.9 & 0.86 & 31.0 & 2.24 & 0.10 & n.a. & n.a. \\
\hline 1984-1987 & 3 & 195.2 & 0.82 & 36.0 & 2.02 & 0.13 & n.a. & n.a. \\
\hline 1987-1991 & 2 & 330.6 & 0.94 & 20.1 & 1.77 & 0.19 & n.a. & n.a. \\
\hline 1991-1993 & 2 & 340.3 & 1.00 & 2.1 & 2.00 & 0.14 & n.a. & n.a. \\
\hline 1993-1999 & 2 & 286.8 & 0.88 & 29.0 & 1.55 & 0.24 & n.a. & n.a. \\
\hline 1999-2002 & 2 & 113.9 & 1.00 & 3.1 & 1.99 & 0.14 & n.a. & n.a. \\
\hline 2002-2006 & 4 & 24.7 & 0.35 & 83.1 & 0.49 & 0.64 & 75.5 & $0.50-0.90$ \\
\hline 2006-2011 & 4 & 111.6 & 0.95 & 18.7 & 3.60 & 0.02 & 218.1 & $<0.05$ \\
\hline
\end{tabular}

\begin{tabular}{|c|c|c|c|c|c|c|}
\hline \multirow[t]{2}{*}{ Species } & \multirow[t]{2}{*}{ Number of catch locations/dates } & \multirow[t]{2}{*}{$n$} & \multicolumn{2}{|l|}{$\delta^{13} \mathrm{C}$} & \multicolumn{2}{|l|}{$\delta^{15} \mathrm{~N}$} \\
\hline & & & $r$ & $P$ & $r$ & $P$ \\
\hline \multirow[t]{2}{*}{ H. laparogramma } & Locations & 10 & 0.851 & 0.002 & 0.597 & 0.068 \\
\hline & Dates & 10 & 0.574 & 0.083 & 0.524 & 0.12 \\
\hline \multirow[t]{2}{*}{ H. pyrrhocephalus } & Locations* & 10 & 0.055 & 0.879 & -0.624 & 0.054 \\
\hline & Dates & 10 & -0.129 & 0.723 & 0.203 & 0.573 \\
\hline \multirow[t]{2}{*}{ H. tanaos } & Locations & 6 & 0.147 & 0.781 & 0.514 & 0.297 \\
\hline & Dates & 6 & 0.297 & 0.568 & -0.037 & 0.945 \\
\hline \multirow[t]{2}{*}{ P. degeni } & Locations & 7 & 0.732 & 0.061 & 0.285 & 0.536 \\
\hline & Dates & 7 & 0.770 & 0.043 & 0.605 & 0.15 \\
\hline
\end{tabular}




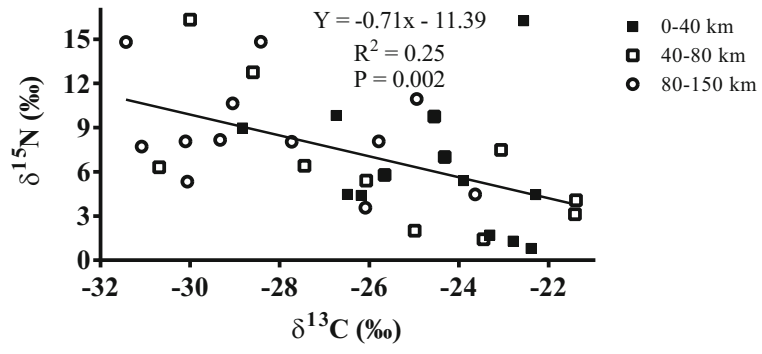

Fig. 5 Stable isotopes of particulate organic matter (POM) collected from inshore and offshore stations along a transect from Mwanza in the south to Port Bell in the north of Lake Victoria in October 1995 and from location V96-5MC in the middle of the lake, from Bugaia Island in the northern part of the lake and from several offshore sites in 1995/1996 (see Campbell et al., 2003a; Mugidde et al., 2003; Hecky et al., 2010)

included quite a high percentage of insects in their diet (8\% chironomids, 5\% Chaoborus larvae and 24\% other insects) before the environmental changes. Moreover, the aquatic insects and especially the decapod crustacean Caridina in Lake Victoria generally have lower $\delta^{15} \mathrm{~N}$ values than zooplankton, although there are exceptions among the insects (Campbell et al., 2003b; Ojwang et al., 2004), which might explain the lack of $\delta^{15} \mathrm{~N}$ increase in 1993 (Fig. 4; Table S4). In 2006, tan included even more fish in their diet than in 1993 (van Rijssel et al., 2015) which is reflected in the increase of $\delta^{15} \mathrm{~N}$ values as well (Figs. 3, 4; Table S4). More consumption of aquatic insects might also explain the lower $\delta^{15} \mathrm{~N}$ values of pyr compared to the closely related species lap from before the environmental changes. Haplochromis laparogramma was almost exclusively feeding on zooplankton during that time and pyr already included some chironomid larvae and insects next to their main prey zooplankton (Kishe-Machumu, 2012; van Rijssel et al., 2015) which might have lowered their $\delta^{15} \mathrm{~N}$ values.

For one species (lap), we were able to perform a Pearson correlation test on the dietary contents with the stable isotopes from the same fish (data from van Rijssel et al., 2015). However, none of the averaged volume percentages of the different food types (zooplankton, phytoplankton, detritus, insects, shrimps or fish) gave a significant correlation with $\delta^{13} \mathrm{C}$ or $\delta^{15} \mathrm{~N}$ in the fish through time (Table S6). The lack of correlation can be caused by three factors: (1) these fish seem to be quite opportunistic regarding their food types. The studied species shifted their diet from mainly small prey (zooplankton/detritus) to a highly diverse diet containing multiple food types such as insects, fish, shrimps, detritus and phytoplankton at the time that large macroinvertebrate numbers increased in their environment (van Rijssel et al., 2015). These lower food web organisms show a high variability in their stable isotope signatures (Campbell et al., 2003b) which might be reflected in the stable isotopes of the fish; (2) the stomach and gut contents only reflect what the fish has been eating that day (or night) and do not always have to reflect fish's diet on the long term; (3) climatic variability seems to be affecting the mixing depths of the Mwanza Gulf (van Rijssel, 2014) which have an effect on the $\delta^{13} \mathrm{C}$ of particulate organic matter (POM) and fish and therefore interfere with stable isotope-food relationships. These three factors make direct dietary-stable isotope correlations hard to detect in these species.

\section{Geographical variation}

A higher number of catch locations resulted in a higher $\delta^{13} \mathrm{C}$ variation. Unfortunately, the dataset we used did not allow us to detect a general trend in offshore and inshore isotopes (heavier $\delta^{13} \mathrm{C}$ and lighter $\delta^{15} \mathrm{~N}$ values inshore versus lighter $\delta^{13} \mathrm{C}$ and heavier $\delta^{15} \mathrm{~N}$ offshore) as has been found by Hecky et al. (2010) and Mbabazi et al. (2010) in Lake Victoria and Lake Kyoga, respectively. However, these studies reported intralake variation on a large scale (from 1 to $150 \mathrm{~km}$ offshore) while our studied transect only covered $5 \mathrm{~km}$. Our results show that the slopes between $\delta^{13} \mathrm{C}$ and $\delta^{15} \mathrm{~N}$ in three out of four species have a similar direction compared to the slope of POM (with the slopes of pyr and tan showing no significant difference with that of POM). However, the slopes of these three species are less steep than that of POM, and so geographical variation can only partly explain the shifts in stable isotope signatures if we assume that the relationship for POM lake-wide applies to Mwanza Gulf. The positive slope of $d e g$ is in the opposite direction of the slope of POM so variation in $\mathrm{deg}$ isotopes can only be explained by a shift to isotopically heavier prey as both $\delta 13 \mathrm{C}$ and $\delta 15 \mathrm{~N}$ increase together from earlier to later years. The species $p y r$ and lap did not extend their habitat to deeper water (as would be expected from the POM data and from the lighter $\delta^{13} \mathrm{C}$ signatures in these species through the 1980 s and 1990s) but rather they occupied shallower 
water (Seehausen et al., 1997b; Kishe-Machumu et al., 2015). However, stomach and gut content analysis revealed a higher intake of chironomids, detritus and molluscs during the late 1980s and 1990s of both species (Katunzi et al., 2003; Kishe-Machumu 2012; van Rijssel et al., 2015), indicating a more benthic feeding behaviour during this period. In contrast, the species tan did extend its habitat from shallow bays to deeper open sublittoral areas. It is still unclear why some species have shifted from shallow to deeper waters while other species showed shifts in the opposite direction. Several causes of these habitat shifts have been suggested and most probably, a combination of these causalities has resulted in the habitat shifts. (1) A shift to the littoral habitat could be a response to heavy predation by Nile perch in the sublittoral zone; (2) the same shift could be a response to lower oxygen levels and reduced water transparency caused by increased eutrophication; (3) the shift from the littoral to the sublittoral habitat might be explained by competitive release and the opportunity to invade previously unoccupied spatial niches and; 4) ecological and morphological adaptive responses might have facilitated the habitat extension to deeper waters (Seehausen et al., 1997b; van der Meer et al., 2012; van Rijssel, 2014; Kishe-Machumu et al., 2015).

Although our dataset does not allow us to make within year comparisons, we suggest that geographical variation in $\delta^{13} \mathrm{C}$ isotopes might be present on a small scale like our research transect in cichlids. Specimens from the two closely related zooplanktivorous species pyr and lap from 1978 were caught all along the transect while fish of these species from 1981 were caught only at the deepest station of the transect, $\mathrm{G}$ (Table S1). Stomach and gut content analysis revealed these fish mainly fed on zooplankton and that there was no within species difference in volume percentages of this prey type before 1987 (van Rijssel et al., 2015).This is why we consider the shift towards lighter $\delta^{13} \mathrm{C}$ values of the two zooplanktivorous species in 1981 compared to 1978 (Figs. 3a, 4a, b) more likely to be the result of geographical variation than a change in diet over time. The observed trend for lighter $\delta^{13} \mathrm{C}$ values in deeper offshore water has been reported on a larger scale by Hecky et al. (2010). They attributed these lighter offshore $\delta^{13} \mathrm{C}$ values to a lower offshore algal (cyanobacteria) productivity and biomass compared to inshore. Although our research transect is only $5 \mathrm{~km}$ wide, the stable isotope data suggest that a similar relation might apply on a smaller scale to the Mwanza Gulf as well. This theory is supported by the findings of Kishe-Machumu et al. (this issue) who found heavier $\delta^{13} \mathrm{C}$ values at the shallow station $\mathrm{J}$ compared to deeper stations in the Mwanza Gulf for two haplochromine cichlid species (including $H$. pyrrhocephalus).

This geographical variation in stable isotopes suggests also that the zooplanktivorous open water species used in this study have a limited dispersal between stations along the transect. It is known that many cichlid species are restricted by bottom types, depths or parts of the water column but a virtual lack of horizontal migration that would be required to explain our data have not been reported for these open water species (Witte, 1981; Witte et al., 2007). On the other hand, these fish have extended their habitat to shallower depths in the past decades indicating that there must be some horizontal migration but probably less than previously thought (Seehausen et al., 1997b; Kishe-Machumu et al., 2015).

\section{Seasonal variation}

Primary producers are known to have within year temporal variation in both $\delta^{13} \mathrm{C}$ and $\delta^{15} \mathrm{~N}$ stable isotopes (Cabana \& Rasmussen, 1996; Post, 2002). Enriched (heavy) $\delta^{13} \mathrm{C}$ and decreased $\delta^{15} \mathrm{~N}$ values of primary producers and primary consumers have been reported during periods of stratification in temperate lakes, but to our knowledge not in tropical lakes (Quay et al., 1986; Zohary et al., 1994; Hodell \& Schelske 1998; Caroni et al., 2012). In addition, larger consumers such as fish have long tissue turnover rates (months to years, Hesslein et al., 1993) and thus are their isotopic signatures representative of their diet for longer periods of time (Post, 2002). This means that if there are small seasonal differences in the lower food web, they will be hard to detect, especially with the dataset used in this study where we were limited to museum material. The heavy $\delta^{13} \mathrm{C}$ and light $\delta^{15} \mathrm{~N}$ values of 2011 found for lap, pyr and tan could, in theory, be considered as being a seasonal effect as these fish were all caught during the warmer wet season when vertical stratification of the water column is more likely than in the cool dry season and this may lead to different availability of food resources. In contrast, comparison of these isotopic signatures from 2011 with stable isotope values from fish caught 
during the wet season in the year 1999 shows that the latter actually had lighter $\delta^{13} \mathrm{C}$ and higher $\delta^{15} \mathrm{~N}$ values, opposite from what one would expect if there is a strong seasonal effect. This leads us to believe that, based on our data, stable isotope signatures are a reflection of the fish's diet and habitat rather than any possible seasonal effect. In addition, so far, no seasonal variation in the diet of Lake Victoria cichlids has been reported (Katunzi et al., 2003; Van Oijen \& Witte, 1996; Kishe-Machumu, 2012; Kishe-Machumu et al., 2008; van Rijssel et al., 2015). Studies on seasonal variation of stable isotope signatures in Lake Victoria cichlids would provide definitive conclusions on this matter.

Signs of increased primary productivity?

Unexpectedly, the $\delta^{13} \mathrm{C}$ values in the studied zooplanktivorous species shifted to lighter values during the 1990s (the perturbed period) where heavier values were expected due to increased demand for $\mathrm{CO}_{2}$ and reduced isotopic fractionation resulting from the increased phytoplankton biomass (Hecky \& Hesslein, 1995; Hecky et al., 2010). However, during the 2000s and especially in 2011, there is a remarkable shift towards heavier $\delta^{13} \mathrm{C}$ in all four species. We hypothesize that this might be the result of increased primary productivity by phytoplankton and evidence for continued eutrophication of the lake. Recently, Cornelissen et al. (2014) found that phytoplankton productivity has increased in the Mwanza Gulf compared to the 1970s (Akiyama et al., 1977). The increase of primary productivity and a basal change of phytoplankton stable isotope signatures could be reflected in the $\delta^{13} \mathrm{C}$ values of the fish when phytoplankton is (unintentionally) absorbed or ingested by the fish (or their prey), as has been found for several other fish species (especially during times of algal blooms, Christoffersen, 1996; Smith et al., 2008). In case of the zooplanktivorous species (which again include mainly zooplankton in 2006 and 2011, van Rijssel et al., 2015), the preyed upon zooplankton (mainly copepods) which should then feed upon cyanobacteria such as Microcystis and Anabaena and diatoms like Nitzschia which have replaced the original phytoplankton (mainly Aulacoseira[Melosira]) in the entire lake (Ochumba \& Kibaara, 1989; Hecky, 1993; Kling et al., 2001; Verschuren et al., 2002) including the Mwanza Gulf (Sekadende et al., 2005; Cornelissen et al., 2014).
However, grazing experiments indicated that Lake Victoria's crustacean zooplankton (mainly cyclopoid copepods) do not control the cyanobacteria-dominated phytoplankton biomass (Branstrator et al., 1998; Lehman \& Branstrator, 1993). In addition, other studies found cyanobacteria (Microcystis) to be toxic, nutritionally inadequate and able to suppress feeding in copepods (Demott \& Moxter, 1991; Demott et al., 1991; Fulton \& Paerl, 1987). On the other hand, there is a growing amount of evidence that copepods can grow and reproduce while feeding on toxic cyanobacteria (Koski et al., 2002; Reinikainen et al., 2002; Nascimento et al., 2008). In fact, several copepod species are known to (rapidly) adapt to increased cyanobacteria exposure enabling these zooplankters to feed upon the phytoplankton (Karjalainen et al., 2006; Colin \& Dam, 2007; Mariani et al., 2013). Therefore, it is not improbable that the cyclopoid zooplankton (or cichlids) of the Mwanza Gulf partly feed upon the increased phytoplankton biomass that may have resulted in heavier $\delta^{13} \mathrm{C}$ values in our fish. A recent stable isotope study on zooplankton caught in the Mwanza Gulf in the wet season of 2011 (same location and period as our fish) showed the same heavy $\delta^{13} \mathrm{C}$ stable isotope values as for our fish (Cornelissen 2015), which supports the above-mentioned theory. Zooplankton grazing experiments on phytoplankton in the Mwanza Gulf would be needed to draw definitive conclusions.

\section{Conclusion}

With the use of a unique long-term formalin preserved sampling dataset, our study shows that stable isotope changes are reflecting dietary and habitat changes of four haplochromine species. In contrast, there does not seem to be a seasonal effect on the stable isotopes. Besides ecological changes, we suggest that the stable isotopes of these fish might be reflecting variation in primary production and varying degrees of eutrophication over the last several decades. This would imply that these haplochromines could serve as indicators of eutrophication.

The temporal variability of stable isotopes in these fishes confirms previous findings that museum specimens can be used to trace historical changes in fish ecology and the aquatic environment. This highlights the need for continued sampling of fish and as well as 
other aquatic organisms important to fish feeding to reconstruct and predict environmental changes in aquatic ecosystems.

Acknowledgments We are thankful for our colleagues from the Haplochromis Ecological Survey Team (HEST) and the Tanzania Fisheries Research Institute (TAFIRI) for support and co-operation during the fieldwork. We also like to thank the two anonymous reviewers for helpful comments and suggestions for improvement of the manuscript. The research and fieldwork was financially supported by The Netherlands Organization for Scientific Research (NWO Grant: ALW1PJ/07030), The Netherlands Foundation for the Advancement of Tropical Research (WOTRO Grants: W87-129, W87-161, W87-189, W84-282, W84-488, WB84-587), by the Section of Research and Technology of the Netherlands' Ministry of Development Co-operation, the Netherlands Organization for International Cooperation in Higher Education (NUFFIC), the International Foundation for Sciences (IFS) and the Schure BeijerinckPopping Fonds.

Open Access This article is distributed under the terms of the Creative Commons Attribution 4.0 International License (http:// creativecommons.org/licenses/by/4.0/), which permits unrestricted use, distribution, and reproduction in any medium, provided you give appropriate credit to the original author(s) and the source, provide a link to the Creative Commons license, and indicate if changes were made.

\section{References}

Akiyama, T., A. A. Kajumulo \& S. Olsen, 1977. Seasonal variations of plankton and physicochemical condition in Mwanza Gulf, Lake Victoria. Bulletin of Freshwater Fisheries Research Laboratory 27(2): 49-61.

Andersen, J. H., L. Schluter \& G. Aertebjerg, 2006. Coastal eutrophication: recent developments in definitions and implications for monitoring strategies. Journal of Plankton Research 28(7): 621-628.

Arrington, D. A. \& K. O. Winemiller, 2002. Preservation effects on stable isotope analysis of fish muscle. Transactions of the American Fisheries Society 131(2): 337-342.

Branstrator, D. K., J. T. Lehman \& L. M. Ndawula, 1998. Zooplankton dynamics in Lake Victoria. In Johnson, T. C. \& E. Odada (eds), Limnology, Climatology and Paleolimnology of the East African Lakes. Gordon and Breach, Amsterdam: 125-133.

Cabana, G. \& J. B. Rasmussen, 1996. Comparison of aquatic food chains using nitrogen isotopes. Proceedings of the National Academy of Sciences of the United States of America 93(20): 10844-10847.

Campbell, L. M., R. E. Hecky, R. Muggide, D. G. Dixon \& P. S. Ramlal, 2003a. Variation and distribution of total mercury in water, sediment and soil from northern Lake Victoria, East Africa. Biogeochemistry 65(2): 195-211.

Campbell, L. M., R. E. Hecky \& S. B. Wandera, 2003b. Stable isotope analyses of food web structure and fish diet in Napoleon and Winam Gulfs, Lake Victoria, East Africa. Journal of Great Lakes Research 29: 243-257.
Caroni, R., G. Free, A. Visconti \& M. Manca, 2012. Phytoplankton functional traits and seston stable isotopes signature: a functional-based approach in a deep, subalpine lake, Lake Maggiore (N. Italy). Journal of Limnology 71(1): 84-94.

Christoffersen, K., 1996. Ecological implications of cyanobacterial toxins in aquatic food webs. Phycologia 35(6S): 42-50.

Colin, S. P. \& H. G. Dam, 2007. Comparison of the functional and numerical responses of resistant versus non-resistant populations of the copepod Acartia hudsonica fed the toxic dinoflagellate Alexandrium tamarense. Harmful Algae 6(6): 875-882.

Cornelissen, I. J. M., 2015. Eutrophication, Nile perch and foodweb interactions in South-East Lake Victoria. PhD-Thesis, Wageningen University.

Cornelissen, I. J. M., G. M. Silsbe, J. A. J. Verreth, E. van Donk \& L. A. J. Nagelkerke, 2014. Dynamics and limitations of phytoplankton biomass along a gradient in Mwanza Gulf, southern Lake Victoria (Tanzania). Freshwater Biology 59(1): 127-141.

Demott, W. R. \& F. Moxter, 1991. Foraging on cyanobacteria by copepods - responses to chemical defenses and resource abundance. Ecology 72(5): 1820-1834.

Demott, W. R., Q. X. Zhang \& W. W. Carmichael, 1991. Effects of toxic cyanobacteria and purified toxins on the survival and feeding of a copepod and 3 species of Daphnia. Limnology and Oceanography 36(7): 1346-1357.

Deniro, M. J. \& S. Epstein, 1977. Mechanism of carbon isotope fractionation associated with lipid synthesis. Science 197(4300): 261-263.

Ferreira, J. G., J. H. Andersen, A. Borja, S. B. Bricker, J. Camp, M. C. da Silva, E. Garces, A. S. Heiskanen, C. Humborg, L. Ignatiades, C. Lancelot, A. Menesguen, P. Tett, N. Hoepffner \& U. Claussen, 2011. Overview of eutrophication indicators to assess environmental status within the European Marine Strategy Framework Directive. Estuarine Coastal and Shelf Science 93(2): 117-131.

France, R. L., 1995. C13 Enrichment in benthic compared to planktonic algae - foodweb implications. Marine EcologyProgress Series 124(1-3): 307-312.

Francey, R. J., C. E. Allison, D. M. Etheridge, C. M. Trudinger, I. G. Enting, M. Leuenberger, R. L. Langenfelds, E. Michel \& L. P. Steele, 1999. A 1000-year high precision record of $\delta^{13} \mathrm{C}$ in atmospheric $\mathrm{CO}_{2}$. Tellus Series B-Chemical and Physical Meteorology 51(2): 170-193.

Fulton, R. S. \& H. W. Paerl, 1987. Toxic and inhibitory effects of the blue-green alga Microcystis aeruginosa on herbivorous zooplankton. Journal of Plankton Research 9(5): 837-855.

Garmendia, M., A. Borja, J. Franco \& M. Revilla, 2013. Phytoplankton composition indicators for the assessment of eutrophication in marine waters: present state and challenges within the European directives. Marine Pollution Bulletin 66(1-2): 7-16.

Goldschmidt, T., F. Witte \& J. Wanink, 1993. Cascading effects of the introduced Nile perch on the detritivorous phytoplanktivorous species in the sublittoral areas of Lake Victoria. Conservation Biology 7(3): 686-700.

Gonzalez-Bergonzoni, I., N. Vidal, B. X. Wang, D. Ning, Z. W. Liu, E. Jeppesen \& M. Meerhoff, 2015. General 
validation of formalin-preserved fish samples in food web studies using stable isotopes. Methods in Ecology and Evolution 6(3): 307-314.

Goudswaard, K. P. C., F. Witte \& J. H. Wanink, 2006. The shrimp Caridina nilotica in Lake Victoria (East Africa), before and after the Nile perch increase. Hydrobiologia 563: 31-44.

Goudswaard, K. P. C., F. Witte \& E. F. B. Katunzi, 2008. The invasion of an introduced predator, Nile perch (Lates niloticus, L.) in Lake Victoria (East Africa): chronology and causes. Environmental Biology of Fishes 81(2): 127-139.

Gu, B. H., A. D. Chapman \& C. L. Schelske, 2006. Factors controlling seasonal variations in stable isotope composition of particulate organic matter in a soft water eutrophic lake. Limnology and Oceanography 51(6): 2837-2848.

Hecky, R. E., 1993. The eutrophication of Lake Victoria. Verhandlungen der Internationalen Vereinigung für Theoretische und Angewandte Limnologie 25: 39-48.

Hecky, R. E. \& R. H. Hesslein, 1995. Contributions of benthic algae to lake food webs as revealed by stable isotope analysis. Journal of the North American Benthological Society 14(4): 631-653.

Hecky, R. E., F. W. B. Bugenyi, P. Ochumba, J. F. Talling, R. Mugidde, M. Gophen \& L. Kaufman, 1994. Deoxygenation of the deep water of Lake Victoria, East Africa. Limnology and Oceanography 39(6): 1476-1481.

Hecky, R. E., R. Mugidde, P. S. Ramlal, M. R. Talbot \& G. W. Kling, 2010. Multiple stressors cause rapid ecosystem change in Lake Victoria. Freshwater Biology 55: 19-42.

Hesslein, R. H., K. A. Hallard \& P. Ramlal, 1993. Replacement of sulfur, carbon, and nitrogen in tissue of growing broad whitefish (Coregonus nasus) in response to a change in diet traced by delta-S-34, delta-C-13 and delta-N-15. Canadian Journal of Fisheries and Aquatic Sciences 50(10): 2071-2076.

Hodell, D. A. \& C. L. Schelske, 1998. Production, sedimentation, and isotopic composition of organic matter in Lake Ontario. Limnology and Oceanography 43(2): 200-214.

Kaehler, S. \& E. A. Pakhomov, 2001. Effects of storage and preservation on the delta C-13 and delta N-15 signatures of selected marine organisms. Marine Ecology Progress Series 219: 299-304.

Karjalainen, M., B. Kozlowsky-Suzuki, M. Lehtiniemi, J. Engstrom-Ost, H. Kankaanpaa \& M. Viitasalo, 2006. Nodularin accumulation during cyanobacterial blooms and experimental depuration in zooplankton. Marine Biology 148(4): 683-691.

Katunzi, E. F. B., J. Zoutendijk, T. Goldschmidt, J. H. Wanink \& F. Witte, 2003. Lost zooplanktivorous cichlid from Lake Victoria reappears with a new trade. Ecology of Freshwater Fish 12(4): 237-240.

Keeling, C. D., 1979. The Suess effect: ${ }^{13}$ Carbon- $-{ }^{14}$ Carbon interrelations. Environment International 2: 229-300.

Kelly, B., J. B. Dempson \& M. Power, 2006. The effects of preservation on fish tissue stable isotope signatures. Journal of Fish Biology 69(6): 1595-1611.

Kiljunen, M., J. Grey, T. Sinisalo, C. Harrod, H. Immonen \& R. I. Jones, 2006. A revised model for lipid-normalizing delta C-13 values from aquatic organisms, with implications for isotope mixing models. Journal of Applied Ecology 43(6): 1213-1222.

Kishe-Machumu, M. A., 2012. Inter-guild differences and possible causes of the recovery of cichlid species in Lake Victoria, Tanzania $\mathrm{PhD}$ thesis, Leiden University.

Kishe-Machumu, M. A., F. Witte \& J. H. Wanink, 2008. Dietary shift in benthivorous cichlids after the ecological changes in Lake Victoria. Animal Biology 58(4): 401-417.

Kishe-Machumu, M. A., J. C. van Rijssel, J. H. Wanink \& F. Witte, 2015. Differential recovery and spatial distribution of haplochromine cichlids in the Mwanza Gulf of Lake Victoria. Journal of Great Lakes Research 41: 454-462.

Kling, H. J., R. Mugidde \& R. E. Hecky, 2001. Recent changes in the phytoplankton community of Lake Victoria in response to eutrophication. In Munawar, M. \& R. E. Hecky (eds), The Great Lakes of the World (GLOW) - Food Web, Health and Integrity. Backhuys Publishers, Leiden: 47-65.

Kolding, J. P., P. Van Zwieten, O. C. Mkumbo, G. Silsbe \& R. E. Hecky, 2008. Are the Lake Victoria fisheries threatened by exploitation or eutrophication? Towards an ecosystem based approach to management. In Bianchi, G. \& H. R. Skjodal (eds), The Ecosystem Approach to Fisheries. Cab International, Wallingford: 309-354.

Koski, M., K. Schmidt, J. Engstrom-Ost, M. Viitasalo, S. Jonasdottir, S. Repka \& K. Sivonen, 2002. Calanoid copepods feed and produce eggs in the presence of toxic cyanobacteria Nodularia spumigena. Limnology and Oceanography 47(3): 878-885.

Lehman, J. T. \& D. K. Branstrator, 1993. Effects of nutrients and grazing on the phytoplankton of Lake Victoria. Verhandlungen der Internationalen Verein Limnologie 25: 846-849.

Mariani, P., K. H. Andersen, A. W. Visser, A. D. Barton \& T. Kiorboe, 2013. Control of plankton seasonal succession by adaptive grazing. Limnology and Oceanography 58(1): 173-184.

Mbabazi, D., B. Makanga, F. Orach-Meza, R. E. Hecky, J. S. Balirwa, R. Ogutu-Ohwayo, P. Verburg, L. Chapman \& E. Muhumuza, 2010. Intra-lake stable isotope ratio variation in selected fish species and their possible carbon sources in Lake Kyoga (Uganda): implications for aquatic food web studies. African Journal of Ecology 48(3): $667-675$.

Mcconnaughey, T. \& C. P. Mcroy, 1979. Food-web structure and the fractionation of carbon isotopes in the Bering Sea. Marine Biology 53(3): 257-262.

Mugidde, R., 1993. The increase in phytoplankton primary productivity and biomass in Lake Victoria (Uganda). Verhandlungen der Internationalen Vereinigung für Theoretische und Angewandte Limnologie 25: 846-849.

Mugidde, R., R. E. Hecky, L. L. Hendzel \& W. D. Taylor, 2003. Pelagic nitrogen fixation in Lake Victoria (East Africa). Journal of Great Lakes Research 29: 76-88.

Nascimento, F. J. A., A. M. L. Karlson \& R. Elmgren, 2008. Settling blooms of filamentous cyanobacteria as food for meiofauna assemblages. Limnology and Oceanography 53(6): 2636-2643.

Ochumba, P. B. O. \& D. I. Kibaara, 1989. Observations on bluegreen algal blooms in the open waters of Lake Victoria. Kenya. African Journal of Ecology 27(1): 23-34. 
Ogawa, N. O., T. Koitabashi, H. Oda, T. Nakamura, N. Ohkouchi \& E. Wada, 2001. Fluctuations of nitrogen isotope ratio of gobiid fish (Isaza) specimens and sediments in Lake Biwa, Japan, during the 20th century. Limnology and Oceanography 46(5): 1228-1236.

Ojwang, W. O., L. Kaufman, A. A. Asila, S. Agembe \& B. Michener, 2004. Isotopic evidence of functional overlap amongst the resilient pelagic fishes of Lake Victoria, Kenya. Hydrobiologia 529(1): 27-35.

Paerl, H. W., L. M. Valdes, J. L. Pinckney, M. F. Piehler, J. Dyble \& P. H. Moisander, 2003. Phytoplankton photopigments as indicators of estuarine and coastal eutrophication. Bioscience 53(10): 953-964.

Peterson, B. J. \& B. Fry, 1987. Stable isotopes in ecosystem studies. Annual Review of Ecology and Systematics 18: 293-320.

Ponsard, S. \& M. Amlou, 1999. Effects of several preservation methods on the isotopic content of Drosophila samples. Comptes Rendus De L Academie Des Sciences Serie IiiSciences De La Vie-Life Sciences 322(1): 35-41.

Post, D. M., 2002. Using stable isotopes to estimate trophic position: models, methods, and assumptions. Ecology 83(3): 703-718.

Post, D. M., C. A. Layman, D. A. Arrington, G. Takimoto, J. Quattrochi \& C. G. Montana, 2007. Getting to the fat of the matter: models, methods and assumptions for dealing with lipids in stable isotope analyses. Oecologia 152(1): 179-189.

Quay, P. D., S. R. Emerson, B. M. Quay \& A. H. Devol, 1986. The carbon cycle for Lake Washington - a stable isotope study. Limnology and Oceanography 31(3): 596-611.

Ramlal, P. S., G. W. Kling, L. M. Ndawula, R. E. Hecky \& H. J. Kling, 2001. Diurnal fluctuations in PCO2, DIC, oxygen and nutrients at inshore sites in Lake Victoria, Uganda. In Munawar, M. \& R. E. Hecky (eds), The Great Lakes of the World (GLOW) - Food Web, Health and Integrity. Backhuys Publishers, Leiden: 67-82.

Reinikainen, M., F. Lindvall, J. A. O. Meriluoto, S. Repka, K. Sivonen, L. Spoof \& M. Wahlsten, 2002. Effects of dissolved cyanobacterial toxins on the survival and egg hatching of estuarine calanoid copepods. Marine Biology 140(3): 577-583.

Sarakinos, H. C., M. L. Johnson \& M. J. Vander Zanden, 2002. A synthesis of tissue-preservation effects on carbon and nitrogen stable isotope signatures. Canadian Journal of Zoology-Revue Canadienne De Zoologie 80(2): 381-387.

Schelske, C. L. \& D. A. Hodell, 1991. Recent changes in productivity and climate of Lake Ontario detected by isotopic analysis of sediments. Limnology and Oceanography 36(5): 961-975.

Schmidt, S. N., J. D. Olden, C. T. Solomon \& M. J. Vander Zanden, 2007. Quantitative approaches to the analysis of stable isotope food web data. Ecology 88(11): 2793-2802.

Seehausen, O., J. J. M. van Alphen \& F. Witte, 1997a. Cichlid fish diversity threatened by eutrophication that curbs sexual selection. Science 277(5333): 1808-1811.

Seehausen, O., F. Witte, E. F. Katunzi, J. Smits \& N. Bouton, 1997b. Patterns of the remnant cichlid fauna in southern Lake Victoria. Conservation Biology 11(4): 890-904.
Sekadende, B. C., T. J. Lyimo \& R. Kurmayer, 2005. Microcystin production by cyanobacteria in the Mwanza Gulf (Lake Victoria, Tanzania). Hydrobiologia 543: 299-304.

Shayo, S. D., C. Lugomela \& J. F. Machiwa, 2011. Influence of land use patterns on some limnological characteristics in the south-eastern part of Lake Victoria. Tanzania. Aquatic Ecosystem Health \& Management 14(3): 246-251.

Smith, J. L., G. L. Boyer \& P. V. Zimba, 2008. A review of cyanobacterial odorous and bioactive metabolites: impacts and management alternatives in aquaculture. Aquaculture 280(1-4): 5-20.

Smith, V. H., 2007. Using primary productivity as an index of coastal eutrophication: the units of measurement matter. Journal of Plankton Research 29(1): 1-6.

Smith, V. H. \& D. W. Schindler, 2009. Eutrophication science: where do we go from here? Trends in Ecology \& Evolution 24(4): 201-207.

Sweeting, C. J., N. V. C. Polunin \& S. Jennings, 2004. Tissue and fixative dependent shifts of delta $\mathrm{C}-13$ and delta N-15 in preserved ecological material. Rapid Communications in Mass Spectrometry 18(21): 2587-2592.

Sweeting, C. J., N. V. C. Polunin \& S. Jennings, 2006. Effects of chemical lipid extraction and arithmetic lipid correction on stable isotope ratios of fish tissues. Rapid Communications in Mass Spectrometry 20(4): 595-601.

Van der Meer, H. J., J. C. van Rijssel, L. C. Wagenaar \& F. Witte, 2012. Photopic adaptations to a changing environment in two Lake Victoria cichlids. Biological Journal of the Linnean Society 106(2): 328-341.

Van Oijen, M. J. P. \& F. Witte, 1996. Taxonomical and ecological description of a species complex of zooplanktivorous and insectivorous cichlids from Lake Victoria. Zool Verh Leiden 302: 1-56.

van Rijssel, J. C., 2014. Adaptive responses to environmental changes in Lake Victoria cichlids. PhD-Thesis, Leiden University.

van Rijssel, J. C., E. S. Hoogwater, M. A. Kishe-Machumu, E. van Reenen, K. V. Spits, R. C. van der Stelt, J. H. Wanink $\&$ F. Witte, 2015. Fast adaptive responses in the oral jaw of Lake Victoria cichlids. Evolution 69(1): 179-189.

Van Rijssel, J. C. \& F. Witte, 2013. Adaptive responses in resurgent Lake Victoria cichlids over the past 30 years. Evolutionary Ecology 27(2): 253-267.

Vander Zanden, M. J. \& J. B. Rasmussen, 1999. Primary consumer $\delta^{13} \mathrm{C}$ and $\delta^{15} \mathrm{~N}$ and the trophic position of aquatic consumers. Ecology 80(4): 1395-1404.

Vander Zanden, M. J. \& J. B. Rasmussen, 2001. Variation in $\delta^{15} \mathrm{~N}$ and $\delta^{13} \mathrm{C}$ trophic fractionation: implications for aquatic food web studies. Limnology and Oceanography 46(8): 2061-2066.

Vander Zanden, M. J., Y. Vadeboncoeur, M. W. Diebel \& E. Jeppesen, 2005. Primary consumer stable nitrogen isotones as indicators of nutrient source. Environmental Science \& Technology 39(19): 7509-7515.

Verburg, P., 2007. The need to correct for the Suess effect in the application of delta C-13 in sediment of autotrophic Lake Tanganyika, as a productivity proxy in the Anthropocene. Journal of Paleolimnology 37(4): 591-602.

Verschuren, D., T. C. Johnson, H. J. Kling, D. N. Edgington, P. R. Leavitt, E. T. Brown, M. R. Talbot \& R. E. Hecky, 2002. History and timing of human impact on Lake Victoria, East 
Africa. Proceedings of the Royal Society Biological Sciences Series B 269(1488): 289-294.

Witte, F., 1981. Initial results of the ecological survey of the haplochromine cichlid fishes from the Mwanza Gulf of Lake Victoria (Tanzania) - breeding patterns, trophic and species distribution - with recommendations for commercial trawl-fishery. Netherlands Journal of Zoology 31(1): 175-202.

Witte, F., T. Goldschmidt, J. H. Wanink, M. J. P. van Oijen, K. P. C. Goudswaard, E. Witte-maas \& N. Bouton, 1992. The destruction of an endemic species flock - quantitative data on the decline of the haplochromine cichlids of Lake Victoria. Environmental Biology of Fishes 34(1): 1-28.
Witte, F., J. H. Wanink \& M. A. Kishe, 2007. Species distinction and the biodiversity crisis in Lake Victoria. Transactions of the American Fisheries Society 136: 1146-1159.

Witte, F., M. Welten, M. Heemskerk, I. van der Stap, L. Ham, H. Rutjes \& J. Wanink, 2008. Major morphological changes in a Lake Victoria cichlid fish within two decades. Biological Journal of the Linnean Society 94(1): 41-52.

Zohary, T., J. Erez, M. Gophen, I. Bermanfrank \& M. Stiller, 1994. Seasonality of stable carbon isotopes within the pelagic food web of Lake Kinneret. Limnology and Oceanography 39(5): 1030-1043. 